\title{
REVIEW
}

\section{Progress of forest certification in China}

\author{
Wenming LU (凶) ${ }^{1}$, Maharaj MUTHOO \\ 1 Chinese Academy of Forestry, Beijing 100091, China \\ 2 Roman Forum, Rome 00124, Italy
}

\begin{abstract}
The Chinese Government is committed to forest certification as a market-based instrument to promote sustainable forest management. Forest certification includes a number of regulations, rules and policy paradigms related to certification and there are numerous challenges facing the uptake of forest certification in China. In particular, the ban on commercial logging in natural forests implemented by the Natural Forest Protection Program has resulted in little demand for forest certification of natural forest management units. However, there are also certification opportunities, such as the certification of non-timber forest products that benefit local communities who depend on forests for the goods and services they provide. This paper provides an overview of progress in forest certification in China, including its development history, organizational structure, scheme documents, certification scopes and standards, accreditation, certification bodies and auditors, and certification logos. The paper also focuses on government support for the supervision and management of forest certification through policy incentives, including the potential government procurement and subsidy policies for certified forest products. Finally, the paper analyzes certified non-timber forest products as an example of the value of certification to promote sustainable forest management and how the concept of forest certification can be used to add value to forests and ensure they are responsibly and sustainably managed. In general, forest certification in China has a clear role in sustainable forest management, both for timber and non-timber forest products.
\end{abstract}

Keywords China Forest Certification Scheme, forest certification, government support, opportunities and challenges, sustainable forest management

Received August 2, 2017; accepted November 21, 2017

Correspondence: luwenmingcaf@126.com

\section{Introduction}

Since its establishment in 1993, forest certification has developed rapidly around the world as an effective marketbased instrument to promote sustainable forest management. There are two major international forest certification systems used in China: the Program for the Endorsement of Forest Certification (PEFC), and the Forest Stewardship Council (FSC). PEFC is an international nonprofit, nongovernmental organization dedicated to promoting sustainable forest management through independent thirdparty certification. FSC is similar to PEFC in its objectives. PEFC is an umbrella organization and works by endorsing national forest certification systems, while FSC is a member-led organization with a centralized accreditation body. In addition, over 40 countries have developed their own national forest certification systems, with the USA and Indonesia each having two national systems. The area of certified forest and the number of chain of custody certificates issued globally increases each year.

China is a global forestry leader for forest resources, timber production, timber processing and manufacturing, timber import and forest products export. This has enabled forest certification to develop rapidly in China. The development process of forest certification in China started in 1995, when the Chinese Academy of Forestry initiated research on the subject. The first FSC chain of custody certificate was issued in 1998, and the first FSC forest management certificate was issued in 2002. The development of the national certification system, the China Forest Certification Scheme (CFCS), started in 2001. Sixteen years later, CFCS is now recognized internationally and is a mainstream modus operandi for ensuring sustainable forest management in China.

\section{Development of CFCS}

\subsection{System development}

CFCS was initiated mainly by the government through the 
State Forestry Administration. From 2001 to 2009, efforts focused on the development of a forest management certification standard and a chain of custody certification standard, the establishment of a certification body, capacity building, pilots for forest management certification, and institutional arrangements.

From 2010 to 2012, CFCS started operations by auditing both forest management practices and tracing certified timber products through a chain of custody. The China Forest Certification Council (CFCC) was established in 2010 as the governing body and operator of CFCS. Also in 2010, the government policy document, Guidance to Rapidly Promote Forest Certification Work, released by the State Forestry Administration, was adopted ${ }^{[1]}$, including an incentive policy to encourage forest certification.

\subsection{System improvement and operation}

In 2012, CFCS became fully operational. In December 2012, the forest management certification standard and chain of custody certification standard were upgraded from forest sector standards into national standards. In February 2014, CFCS was endorsed by PEFC. The scope of certification was also extended to include areas other than forest management and chain of custody certification. In June 2015, the government regulating policy document, Forest Certification Rules, was also revised by the Certification and Accreditation Administration and the State Forestry Administration ${ }^{[2]}$.

\section{Overview and development of CFCS}

\subsection{Organizational structure}

CFCC is the highest governing body of CFCS, and its daily work is managed by its Secretariat. The CFCS organization structure includes technical committee, standard development working group, stakeholders forum, dispute resolution committee, and other groups (Fig. 1).

\subsection{Certification scope and success}

CFCS not only adopts international practices, but also has creative measures. This means CFCS has been able to extend its scope and offers certification in other areas. This includes certifications of bamboo forest management, nontimber forest products management, commercially-managed precious and endangered species, forest eco-environmental services, carbon sequestration forests, forest fire, and forest flowers.

The certification of non-timber forest products management has proven to be particularly successful. One of the key reasons for this success is the ban on commercial logging within natural forests under the Natural Forest Protection Program. Improvements to the livelihoods of local communities, who use these forests for provision of goods and services, have also been an important factor in the success and application of forest certification.

\subsection{Certification standards}

Each certification process has a corresponding certification standard but as certification is voluntary, none of the certification standards is compulsory. To ensure consistency in the auditing procedures across all certification activities, CFCC has developed corresponding audit directives for certification bodies and also developed corresponding operational manuals to help companies improve their management levels and achieve certification.

The new Forest Certification Rules jointly issued by the Certification and Accreditation Administration and the State Forestry Administration in 2015 stipulates that all forest certification conducted in China is to be under the national standards released by the Standardization Administration of China or forest sector standards released by the

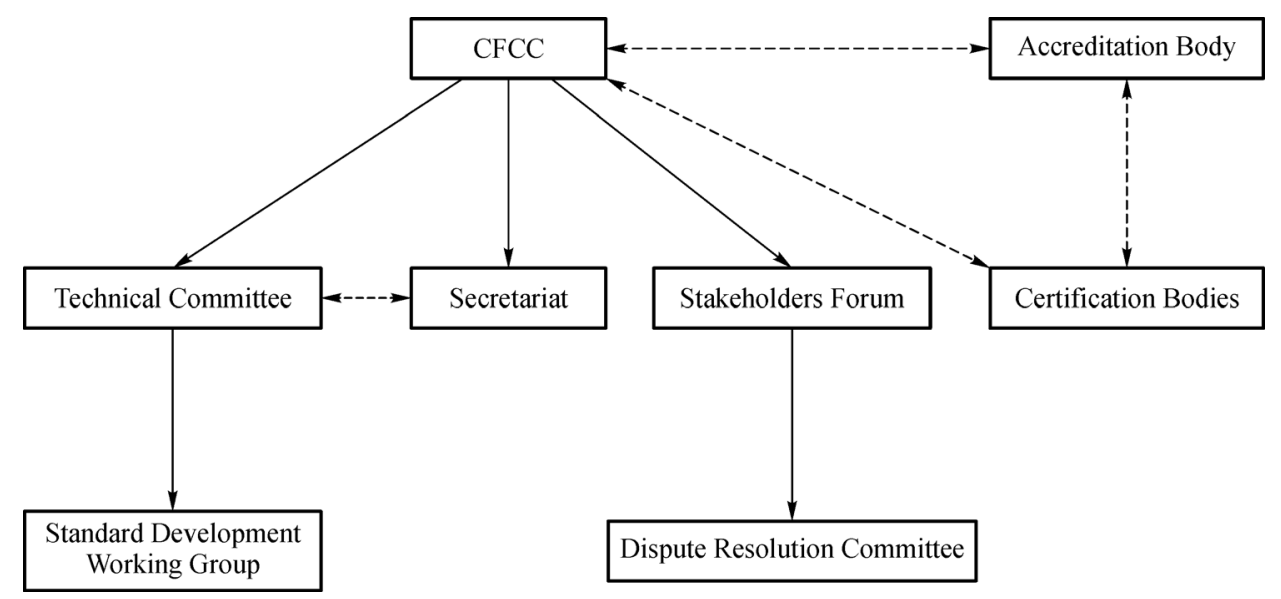

Fig. 1 Organizational structure of China Forest Certification Scheme (CSCF) operated by China Forest Certification Council (CFCC) 
State Forestry Administration.

By the end of June 2017, CFCC had issued 25 standards, including nine certification standards (two national standards and seven forestry sector standards), nine audit directives and seven operational manuals.

\subsection{Accreditation and certification bodies}

According to relevant laws and regulations, there is only one accreditation body in China: The China National Accreditation Service for Conformity Assessment. It is a member of the International Accreditation Forum representing China. It is also the accreditation body for CFCS. According to the new Forest Certification Rules, it issued a new Accreditation Scheme for Forest Certification Bodies in $2015^{[3]}$, which is used to guide the accreditation of forest certification bodies in China.

According to relevant laws and regulations, all certification bodies (including forest certification bodies) have to be approved by the Certification and Accreditation Administration and registered in the government department of industry and commerce. All certification auditors also have to be registered with the China Certification and Accreditation Association and the Registration Criteria for Forest Certification were revised according to the new Forest Certification Rules.

\subsection{Certification logos}

The CFCC logo includes the logo itself and corresponding descriptions. The CFCC logo consists of an image and a code (Fig. 2). The image includes two ginkgo leaves, one sustainable ring and the acronym, CFCC. Figures 3 and 4 show the CFCC logo and examples of its use. CFCC also develops Usage Rules for China Forest Certification $\log o^{[4]}$.

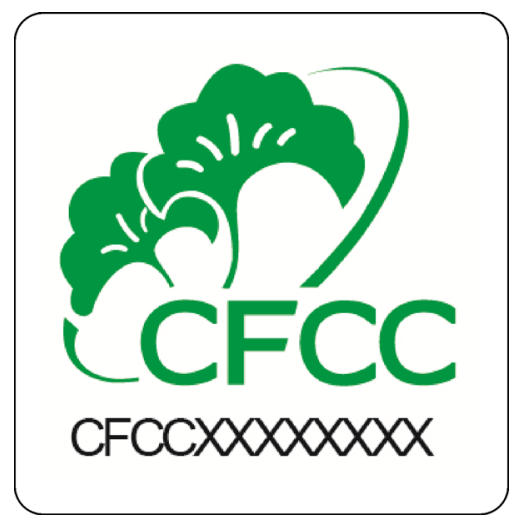

Fig. 2 CFCC logo

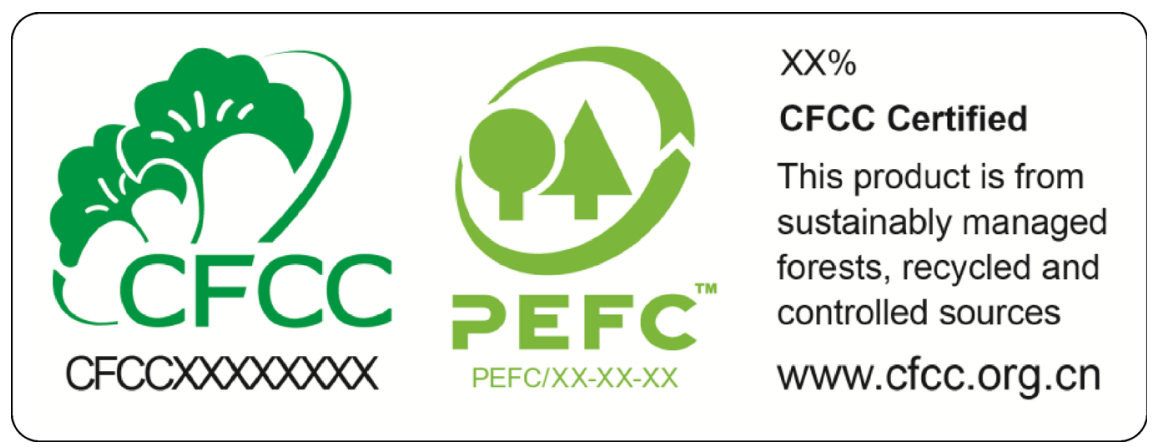

Fig. 3 Certification logo for general timber products

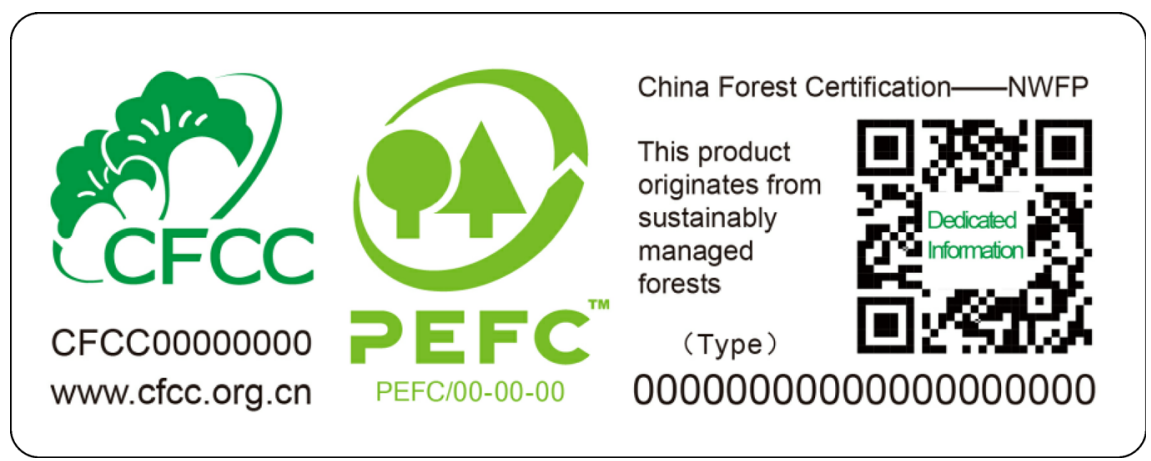

Fig. 4 Certification logo for non-timber forest products 


\section{Government support}

The Chinese Government attaches great importance to forest certification, especially under CFCS. The State Forestry Administration initiated and promoted the establishment of CFCS. It has adopted a series of policy support measures and works with the Certification and Accreditation Administration to jointly supervise and monitor forest certification activities in order to promote a healthy, stable and well oriented development of forest certification in China.

The State Forestry Administration established a Leading Group on Forest Certification Work in China in 2001. It has also established a Division of Certification Management under its Science and Technology Development Center to govern all forest certification work in China, and to act as the Secretariat of CFCC to manage the operation of CFCS.

The State Forestry Administration allocates an annual budget of several million CNY through its Science and Technology Development Center as a special fund for forest certification work, including standard development, pilot training and demonstration, policy research, and international cooperation.

The State Forestry Administration commissioned the Chinese Academy of Forestry to conduct two studies of government policies that will be highly conducive to the promotion of forest certification, as and when adopted.

\subsection{Potential government procurement policy for certified forest products}

Government procurement in China is a highly effective policy instrument for the promotion of the development of particular sectors. Due to the low percentage of certified forest products in the marketplace, it will take some time to fully implement such a policy instrument. The following three-step road map is proposed for the government to adopt such a policy at the appropriate time $e^{[5]}$

(1) Gradually revising the standard, Technical Requirements for Environmentally Labeled Products, by defining $\mathrm{CFCC} / \mathrm{PEFC}$ as part of the requirements for timber materials. This standard is already incorporated into government procurement lists for environmentally-labeled products.

(2) Prioritizing, at an appropriate time, the procurement of $\mathrm{CFCC} / \mathrm{PEFC}$ certified paper products within all government departments, State-owned companies and government funded organizations in the forestry sector.

(3) Incorporating, at an appropriate time, all CFCC/ PEFC certified forest products into government procurement lists.

Given that government procurement in China accounts for a substantial proportion of total GDP, if certified forest products are incorporated into government procurement policy, it could have a significant positive impact on forest certification and sustainable forest management.

\subsection{Potential government subsidy policy for certified forest products}

Government subsidies in China are also an effective policy instrument for promoting the development of particular sectors. Three policy options are proposed for the government to adopt at an appropriate time ${ }^{[6]}$.

(1) Directly subsidizing certified companies: any CFCC/PEFC certified company (especially forest management units and forest products processing and retailing companies) will get a subsidy from the government. The subsidy discount would be based on the certified area of the forest management unit or annual sales of the forest products processing and retailing company. This policy option is similar to the current government subsidy policy for solar photovoltaic products.

(2) Indirectly subsidizing buyers: any consumer buying CFCC/PEFC certified forest products will get a discount. The discount would be subsidized directly by the government to the sellers, or indirectly by the government to the buyers. The discount would be a certain percentage of the sales price. This policy option is similar to the former government subsidy policy for home appliance in rural areas.

(3) Subsidizing both sides: this is a combination of the two policy options above. The government may directly subsidize the CFCC/PEFC certified forest management units or forest products processing and retailing companies, and also indirectly subsidize the buyers. This policy option is similar to the current government subsidy policy for electric vehicles.

\section{Status of forest certification in China}

At present, there are three different forest certification systems in the Chinese market: CFCC, PEFC and FSC.

The progress in these forest certification systems by December 2016 is summarized below.

(1) CFCC: 8.75 million ha of certified forest area and 29 chain of custody certificates issued.

(2) PEFC: globally, 303 million $\mathrm{hm}^{2}$ of certified forest area and 10968 chain of custody certificates issued. In China, PEFC certified forest area is the same as CFCC, due to the endorsement, which was 8.75 million $\mathrm{hm}^{2}$. There were 283 PEFC chain of custody certificates issued.

(3) FSC: globally, 194 million $\mathrm{hm}^{2}$ of certified forest area and 32622 chain of custody certificates issued. In China, there were 4811 chain of custody certificates issued, the highest number of certificates per country in the world, and $840000 \mathrm{hm}^{2}$ of certified forest area- only about one tenth of CFCC certified forest area. 
Although FSC was the first forest certification system, which certified forest management (in 2002) and chain of custody (in 1998) in China, with the development of CFCC, with its endorsement by PEFC in February 2014, and with the strong support of the Chinese Government, the prominence of FSC is decreasing, due also to the conflict between its certification standards and China's relevant laws and regulations ${ }^{[7,8]}$. The number of FSC chain of custody certificates is still high due to the strong demand in international markets, but its area of certified forest has decreased significantly compared with the rapid increase of CFCC/PEFC certified forest area.

In 2015, China achieved the biggest increase in PEFC certified forest area of all countries with a PEFC endorsed national forest certification system and in 2016, China achieved the third largest increase in chain of custody certificates via the PEFC alliance.

\section{Certification for non-timber forest products management}

The main purpose of forest certification in China is to promote sustainable management of forests through the price premium gained for certified timber products. However, the certification of non-timber forest products products is increasingly important due to the Natural Forest Protection Program. This is particularly evident in natural forest area, where commercial logging is banned.

To promote the sustainable management and utilization of non-timber forest products, a special and separate certification standard for non-timber forest products certification (Forest certification in China- Non-timber forest products management) was adopted by CFCC in $2014^{[9,10]}$. This is the first of its kind in the world, which demonstrates its great importance for forest certification globally. By the end of 2016, 7.5 million $\mathrm{hm}^{2}$ of forests in China were certified, predominantly for non-timber forest management. Seven categories of certified non-timber forest products (nuts, berries, fungus, wild vegetables, honey, beverages and fruits) were labeled and offered for sale. Most of the certified non-timber forest products were from the Heilongjiang Province, an important natural forest region in China. The first two certificates for nontimber forest products management were issued to Chaihe Forest Industry Bureau and Yingchun Forest Industry Bureau, both in Heilongjiang Province, in December, 2013.

In the State-owned forestry company of Chaihe Forest Industry Bureau, all of its $345801 \mathrm{hm}^{2}$ of forest is certified for non-timber forest products management with 73 nontimber forest products in six categories. Four categories of certified non-timber forest products are labeled and sold in seven exclusive stores in Beijing, Harbin and Mudanjiang. Moreover, the company is now selling their certified nontimber forest products in over 50 commercial agencies in and around China. As most certified non-timber forest products are edible, the market perspective is promising as an increasing number of customers are recognizing certified products due to the CFCC label, providing them with assurance that the edible non-timber forest products originate from sustainably managed forests. The total sales volume of all certified non-timber forest products by this company increased from $86 \mathrm{t}$ in 2014 to $635 \mathrm{t}$ in only the first half of $2015^{[11]}$. Both the company and its staff, as well as local communities, are highly satisfied with the outcome of certification of non-timber forest products. Primarily this was because their economic returns increased, but also because it provided an incentive to mobilize forest management for both sustainable production of timber and non-timber forest products.

In general, the primary income of forest workers in areas where logging is banned originates from government subsidies to take care of these forests. As this income is low, many people have to make money from additional sources, such as the collection of non-timber forest products. The price premium of processed certified nontimber forest products in the market also promotes the price premium of the certified raw materials. The certification of non-timber forest products, therefore, benefits these forest workers who manage these forests and the goods and services they provide, and provides income to support local communities through sale of certified raw materials to factories for further processing.

Finally, the certification of non-timber forest products promotes sustainable forest management in areas where no commercial logging is allowed, and without this incentive, the forest management units have little interest in forest certification or sustainable forest management.

\section{Discussion}

\subsection{Opportunities}

The Chinese Government attaches great importance to forest certification, which has helped promote its development within the country. The likely adoption of government procurement and subsidy policies will greatly help increase the domestic market for certified timber and nontimber forest products ${ }^{[5,6]}$.

Chinese consumers are increasingly aware of the environmental benefits of buying certified forest-based products. By buying these products at a higher price, they provide a price premium to all participants in the supply chain. This has also become a motivator for promoting forest certification, and consequently, promoting sustainable forest management.

Another opportunity for forest certification in China is the implementation of the EU Timber Regulation and US Lacey Act Amendment ${ }^{[12]}$, which aim to curb illegal logging and associated trade. Although the EU Timber 
Regulation does not directly recognize certified timber products as legally sourced, such as licensing by the Voluntary Partnership Agreement or Convention on International Trade in Endangered Species of Wild Fauna and Flora, certified timber products are normally regarded as low risk for entering the EU market ${ }^{[13]}$. This is broadly applicable in China, as most forest certification systems have a due diligence system to verify the legality of noncertified raw materials, while all their certified raw materials are regarded as both legal and sustainable.

\subsection{Challenges}

There are still a number of challenges for forest certification in China. The Natural Forest Protection Program, which prohibits all commercial logging of natural forests, decreases demand and application of forest certification in natural forest management units. In addition, the demand for forest certification in the domestic market is still weak and government support through government procurement and subsidy policies would be important to foster the development of domestic markets for certified forest products ${ }^{[5,6]}$.

Furthermore, the cost of forest certification is still too high for forest management units. Increasing competition among the growing number of government-approved certification bodies (currently 16) has meant direct costs are reducing. However, the indirect costs are still high due to the poor forest management level in many forest management units, where it costs them a significant amount to bridge the gap between the certification standard and their current management performance.

\section{Conclusions}

Sustainable development has been a common and important commitment by the international community, particularly since the 1992 Rio Earth Summit ${ }^{[14]}$. This has been further strengthened through the Sustainable Development Goals adopted by United Nations member countries in $2015^{[15]}$.

Sustainable forest management is a forest sector strategy in many countries, including China. There are several approaches to achieve sustainable forest management, such as law enforcement and requisite revision of relevant laws, regulations and rules, designing, revising and implementing appropriate national forest programs, criteria and indicators for sustainable forest management, and related guidelines and standards.

The Chinese example shows the commitment of the country and its governance system for delivering sustainable forest management by developing a national forest certification system, and in obtaining international recognition for the process. The national-based approach enables local stakeholders to participate to the full extent, comprehensive consideration of existing forest governance and regulatory frameworks, and alignment of existing forest ownership structures and management practices. Furthermore, it ensures that sustainable forest management at a local level not only mirror global requirements, but incentivizes and give special consideration to the local understanding and significance of the three pillars of sustainability: environmentally sound, socially responsible and economically viable. International recognition, using CFCS through PEFC, thereby demonstrates that CFCS meets all international requirements, in addition to national ones.

This national ownership of forest certification in China holds the potential for strong public support, including various governmental subsidies to guide the development of forest certification. Ultimately, this will help mainstream sustainable forest management and forest certification conjointly in the country and beyond by ensuring the responsible production, processing and trade in timber and non-timber forest products. CFCS, which is being developed and supported by the China Academy of Forestry, is a model example of applying, supporting and strengthening the stewardship of sustainable forest management for present and future generations.

Acknowledgements This work was supported by forest certification related projects by the Science and Technology Development Center of the State Forestry Administration.

Compliance with ethics guidelines Wenming $\mathrm{Lu}$ and Maharaj Muthoo declare that they have no conflicts of interest or financial conflicts to disclose.

This article is a review and does not contain any studies with human or animal subjects performed by any of the authors.

\section{References}

1. State Forestry Administration. Guidance to rapidly promote forest certification work, 2010 (in Chinese)

2. Certification and Accreditation Administration, State Forestry Administration. Forest certification rules, 2015 (in Chinese)

3. China National Accreditation Service for Conformity Assessment. Accreditation scheme for forest certification bodies, 2015 (in Chinese)

4. China Forest Certification Council. Usage rules for China forest certification logo, 2012 (in Chinese)

5. Lu W M, Li Q J. Policy research report: government procurement policy for certified forest products, 2014 (in Chinese)

6. Lu W M, Li X Y. Policy research report: government subsidy policy for certified forest products, 2015 (in Chinese)

7. Xiao J M, Wan J. A discussion of conflicts between FSC standard and China's laws and regulations. World Forestry Research, 2011, 24(1): 60-62 (in Chinese)

8. Liu X L, Zheng X X, Xu B, Huang W B. Current situation and development trend of forest stewardship council in China. Journal of Beijing Forestry University: Social Sciences, 2010, 9(3): 86-90 (in Chinese) 
9. State Forestry Administration. Forest certification in China-nontimber forest products management (LY/T 2273-2014), Beijing: China Standard Press, 2014 (in Chinese)

10. Li Q J, Chen S Z, Hu Y J. Current situation of non-timber forest products certification. World Forestry Research, 2016, 29(1): 14-18 (in Chinese)

11. Hu Y J. Investigation report for non-timber forest products management certification, 2015 (in Chinese)

12. Bai Q Y, Lu W M. Comparative analysis on legality between CFCC chain of custody certification standard and European Union timber regulation. World Forestry Research, 2014, 27(3): 92-96 (in Chinese)

13. Xu B, Li Y, Li J. The strategy analysis on reactions of China's forest products export enterprises to EU timber regulation. World Forestry Research, 2014, 27(4): 55-60 (in Chinese)

14. United Nations Conference on Environment and Development. Rio declaration on environment and development, 1992

15. United Nations. Sustainable development goals, 2015 